\title{
MAINTAINING THE HEALTH OF A RURAL COMMUNITY BY WORKING TOWARDS RESILIENCE AND SUSTAINABILITY
}

Keith Whiddon

\section{INTRODUCTION}

Rural communities have particular issues and needs. They contribute significantly to the economy, yet too often service provision designed for urban areas is not appropriate or affordable for rural communities.

The United Kingdom (UK) is currently going through an unprecedented period of change, politically, economically and socially. The impact on small rural communities is far more significant than on urban areas, with their inherent economies of scale and superior connectivity. Never has there been a more important time for the UK to strive to make its communities resilient to such change and ultimately sustainable for the future for each one of its citizens.

The rural areas of England cover 90 percent of its land and house 17 percent of its people. There are 524,000 registered businesses in rural England, employing up to 3.7 million people and with an annual turnover of $€ 404$ billion. In these rural areas, 22 percent of the paid employment now works from home, while in urban areas the figure is only 13 percent (House of Lords Select Committee on the Rural Economy, 2019).

As an illustration, while rural Shropshire and the City of Nottingham have similar populations, one might expect urban Nottingham to have a far greater number of business enterprises. This is not the case: there are a total of 15,710 enterprises in Shropshire, while only 9,035 in Nottingham (Barrow, 20 I8). The romantic notion that rural areas are unchanging is false. In reality, England's rural economies have already changed markedly, and further change is inevitable. Once dominated by agriculture, they are now as economically diverse as urban economies, contributing a significant amount to the national economy with the potential to flourish and contribute even more to the nation's wellbeing and prosperity.

In terms of social justice (the distribution of wealth, opportunities and privileges within a society), inequality and sparsity, English rural areas face serious challenges and constraints in providing services and infrastructure. These include the unaffordability of housing by comparison with towns and cities; slower broadband and patchy mobile coverage; and recent declines in service provision - for example, in public transport and banking facilities, and businesses facing skills shortages and difficulty accessing finance. A lack of clarity over what will happen as the UK leaves the European Union means that these factors could get worse before they get better.

The result is that many rural communities now feel left behind. These communities deserve an equitable share of service provision and funding. Focusing on delivery in larger settlements is not a fair option. "No resident or business should be disadvantaged unreasonably by their rural location." (House of Lords Select Committee on the Rural Economy, 2019, p. 7). 


\section{BACKGROUND}

The terms 'resilience' and 'sustainability' are in common usage in contemporary writing to describe rural communities.

Resilience is the ability and capacity of a community to adapt to sudden change, to overcome unexpected problems. The concept of community resilience has mostly been applied to settlements responding to and recovering from an adverse physical event, such as a flood or earthquake. However, the term is equally applicable when political, economic or social events threaten the stability of the community, such as the proposed closure of a library or the removal of a subsidy for a bus service.

Sustainability is the long-term capacity for prosperity, growth and well-being. It is the ability or capacity of a community to take what it needs now, without compromising the potential for people in the future to meet their needs. Both resilience and sustainability function together as an integrated system (Figure I).

While a community can often show the resilience to adapt to the loss of service provision by making alternative arrangements, there may come a point when such losses become too great and the sustainability of the whole community is left in jeopardy. As a result, many rural areas are locked into a "circle of decline" by a shortage of jobs, sustainable business activity and inadequate and declining services (Figure 2).

Writing in 2015, Alvarez (NESTA, 2015) drew an interesting parallel between Maslow's "needs pyramid" (Maslow, 1943) and the "needs of a community," arguing that just as individuals need to fulfil certain basic needs to be able to fulfil higher-order ones, then so do communities, as they are comprised of groups of individuals (Figure 3).

An insufficiency, unfair allocation or lack of access to resources can result in communities becoming unsustainable. In the UK, a number of serious political, economic and social issues threaten the sustainability of rural settlements, including:
Capacity over time in face of disturbances

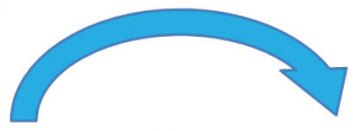

\section{Resilience Sustainability}

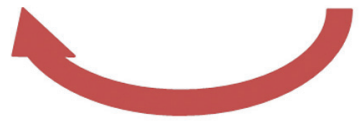

\section{Capacity to preserve the system in the long-run}

Figure I. Resilience and sustainability functioning as a system. Source: Author - based on Musker (2015).

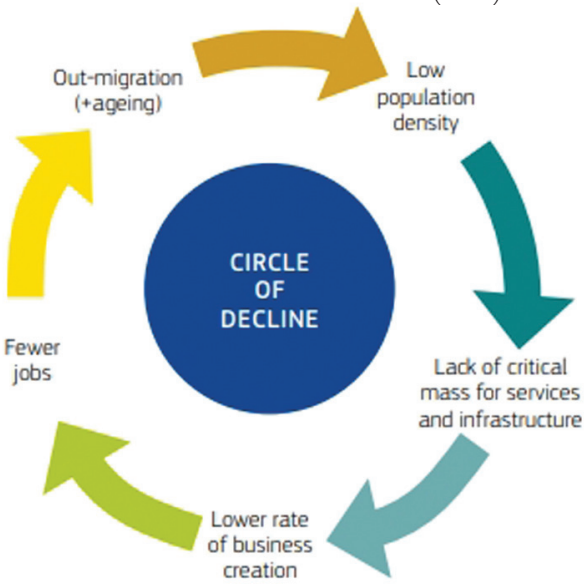

Figure 2. The circle of decline.

Source:The European Network for Rural Development, 2018 (European Commission, 20 I8a).

Reproduced with permission.

\section{Self-Actualization}

Pursue talent, creativity, fulfillment

Self-Esteem

Achievement, Mastery, Recognition

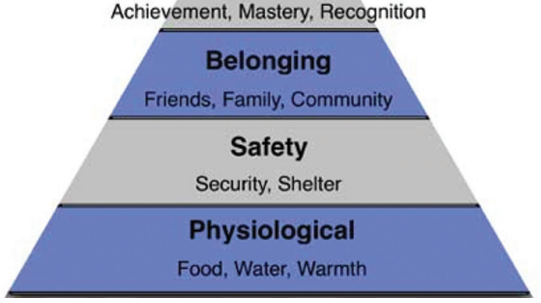

Figure 3. The "needs pyramid" for communities. Maslow pyramid (1943). Source: Alvarez (2015). 
- $\quad$ Fuel poverty - ten million people spend more than 10 percent of their income just to keep warm;

- $\quad$ Food poverty - 5 percent of the population face malnutrition; 26 percent are obese due to food poverty;

- Health inequalities - people living in deprived areas have 7.5 years less life expectancy

- Social isolation - I in 8 lack a friend or family member with whom they are in daily contact;

- Financial exclusion - 8 million people lack a bank account, leaving them $£ 1000$ per year worse off.

(Alvarez, 2015)

These issues are important indicators of sustainability. When applied to the "needs pyramid for communities," all five levels of "need" are required to be met and maintained for a community to be regarded as sustainable (Figure 4).

In his book The Resilience Compass, Wilding highlights four characteristics critical for a community to be sustainable (Figure 5). These include healthy and engaged people; creating a localised economy; crosscommunity links; and building a creative, inclusive culture.

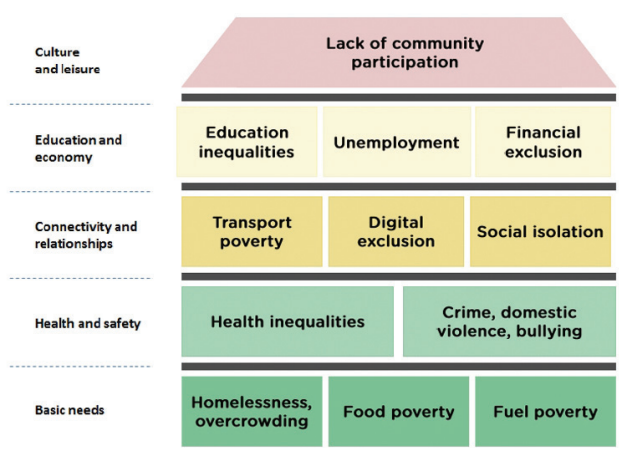

Figure 4. The needs hierarchy of a sustainable community. Source: Alvarez (20।5).

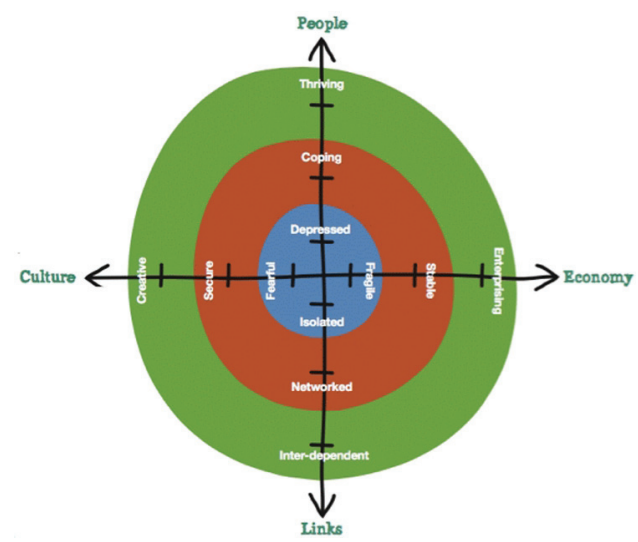

Figure 5. The resilience compass. Source:Wilding (20I I). Reproduced with the permission of The Carnegie Trust.

The outer concentric ring of the compass represents the higher order characteristics found in sustainable communities, in much the same way as outlined by Alvarez in his "needs pyramid for communities."

\section{COMMUNITY PROFILE}

Bishop's Castle, which forms the case study for this paper, is a small English rural market town in the remote South Shropshire Hills, close to the Welsh border. It is a medieval settlement with a large number of historic buildings and an extensive Conservation Area covering the entire town centre.

With a population of just 1893 (UK Office for National Statistics 20 I I), it remains one of the smallest towns in England, yet is the service centre for an extensive hinterland and supports a significant tourist population throughout the year.The town has a well-earned reputation for the arts and music.

Despite its modest size, Bishop's Castle boasts a theatre-cum-leisure centre with swimming pool, a library, a community hospital, a doctor's surgery, three aged-care facilities, a business support and resources facility and a cattle market, as well as six public houses and two breweries. The local community values such services and there is a very strong will to preserve them through the current period of austerity. 


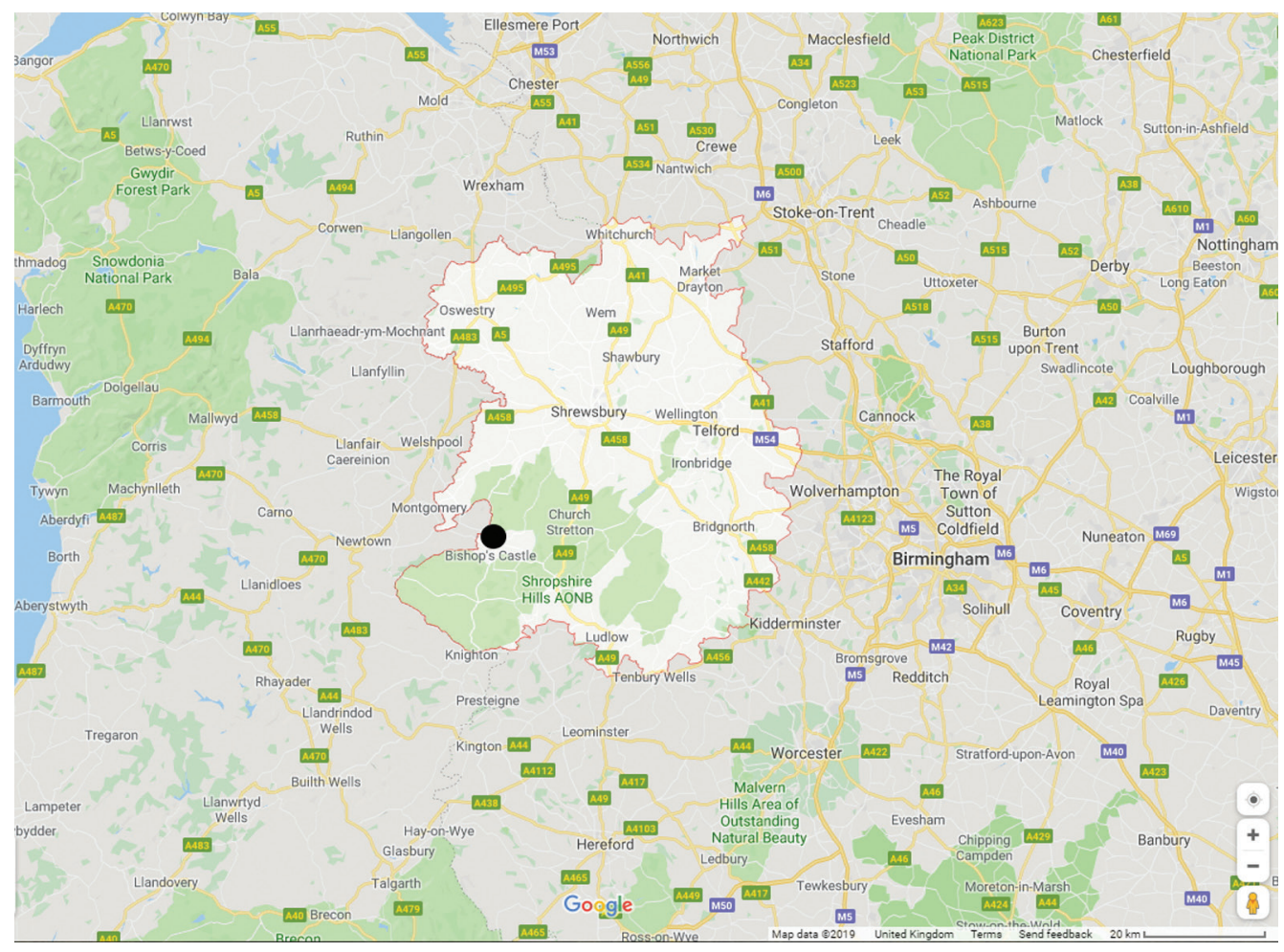

Figure 6. Map showing the location of Bishop's Castle and Shropshire within the West Midlands region. Source: Map data @2019 Google.

Being a small, remote rural town presents some significant economic and social challenges. Access to employment and the need for more affordable housing are seen as the key requirements to ensure the retention of young people and families, thereby avoiding becoming a retirement town. The demographic profile shows that children and young people make up a lower proportion of the town's population than in Shropshire as a whole. However, 63.5 percent of the population are of working age, a higher proportion than the average for Shropshire (60 percent), the West Midlands (62 percent) and the UK as a whole (63 percent) (Shropshire Council, 20 I7-18).

The three largest employment sectors are health (26.5 percent), manufacturing (22 percent) and retail (I 4.4 percent). Eighty-eight percent of the businesses in Bishop's Castle employ fewer than five people, with 5.8 percent employing between five and nine people. Fewer than 5 percent have a workforce of 20 or more (Shropshire Council, 2017-18).

There is nearly a two-fold difference in mental health spending across England. The biggest spending authority is South Yorkshire and Bassetlaw at $£ 220.63$ per person, per year, whereas Shropshire remains the second lowest spending authority in the country at just $£$ | 34.77. Covering a large hinterland, Bishop's Castle Medical Practice has around 5200 registered patients. In common with many rural communities, the community has a disproportionately high percentage of the elderly. Figure 7 compares national and local figures for disease prevalence, showing that Bishop's Castle has a higher than average incidence of age-related illness and a higher than average demand on local heath provision, despite inequitable funding. 
HOUSE OF COMMONS

LIBRARY

DISEASE PREVALENCE IN ENGLAND: LOCAL ESTIMATES

Jan-19

\begin{tabular}{|l|l|l|r|r|r|l|r|l|r|}
\hline MSOA & LA & $\begin{array}{l}\text { Atrial } \\
\text { Fibrilliation }\end{array}$ & Asthma & Cancer & $\begin{array}{l}\text { Coronary Heart } \\
\text { Disease }\end{array}$ & $\begin{array}{l}\text { Chronic } \\
\text { Kidney } \\
\text { Disease }\end{array}$ & COPD & $\begin{array}{l}\text { Cardiovascular } \\
\text { Disease (Primary } \\
\text { Prevention) }\end{array}$ & Dementia \\
\hline & $\begin{array}{l}\text { England } \\
\text { average }\end{array}$ & $1.9 \%$ & $5.9 \%$ & $2.7 \%$ & $3.1 \%$ & $4.1 \%$ & $1.9 \%$ & $1.1 \%$ & $0.8 \%$ \\
\hline Bishop's Castle & Shropshire & $2.6 \%$ & $6.6 \%$ & $4.0 \%$ & $3.9 \%$ & $7.0 \%$ & $2.0 \%$ & $1.1 \%$ & $1.0 \%$ \\
\hline
\end{tabular}

\begin{tabular}{|c|c|r|r|r|r|r|r|r|r|}
\hline MSOA & \multicolumn{1}{|c|}{ LA } & Depression & Diabetes & Epilepsy & Heart Failure & $\begin{array}{c}\text { High Blood } \\
\text { Pressure }\end{array}$ & $\begin{array}{c}\text { Learning } \\
\text { Disabilities }\end{array}$ & $\begin{array}{c}\text { Serious Mental } \\
\text { Illness }\end{array}$ & \begin{tabular}{c} 
Obesity \\
\hline
\end{tabular} \\
\hline $\begin{array}{c}\text { England } \\
\text { average }\end{array}$ & $9.8 \%$ & $6.7 \%$ & $0.8 \%$ & $0.8 \%$ & $13.8 \%$ & $0.5 \%$ & $0.9 \%$ & $9.7 \%$ \\
\hline Bishop's Castle & Shropshire & $10.0 \%$ & $7.0 \%$ & $0.8 \%$ & $0.9 \%$ & $17.6 \%$ & $0.9 \%$ & $0.7 \%$ & $10.7 \%$ \\
\hline
\end{tabular}

\begin{tabular}{|c|c|r|r|r|r|r|}
\hline MSOA & LA & $\begin{array}{c}\text { Peripheral Arterial } \\
\text { Disease }\end{array}$ & $\begin{array}{c}\text { Palliative } \\
\text { Care }\end{array}$ & $\begin{array}{c}\text { Rheumatoid } \\
\text { Arthritis }\end{array}$ & $\begin{array}{c}\text { Stroke \& } \\
\text { Iransient } \\
\text { Ischaemic Attack }\end{array}$ & Osteoporisis \\
\hline & $\begin{array}{c}\text { England } \\
\text { average }\end{array}$ & $0.6 \%$ & $0.4 \%$ & $0.7 \%$ & $1.7 \%$ & $0.6 \%$ \\
\hline Bishop's Castle & Shropshire & $0.9 \%$ & $0.5 \%$ & $1.0 \%$ & $2.7 \%$ & $1.1 \%$ \\
\hline
\end{tabular}

Figure 7. Disease prevalence in England and Bishop's Castle.

Source: Author-adapted data from House of Commons Library (2019).

Shrewsbury and Telford Hospital NHS Trust has approximately 628 inpatient beds and 43 day-case beds and 44 children's beds located in two sites: The Princess Royal Hospital in Telford and Royal Shrewsbury Hospital in Shrewsbury. Both hospitals provide a wide range of acute services including accident and emergency, outpatients, diagnostics, inpatient medical care and critical care and serve nearly half a million people in Shropshire and midWales.

Recently, Shropshire's Future Fit programme has determined that "planned hospital care" will take place at Telford's Princess Royal Hospital, while the Royal Shrewsbury Hospital will become a specialist "emergency care" site only. Telford Hospital is 34 miles from Bishop's Castle, with no direct public transport service, making access impossible for those without their own transport.

Bishop's Castle has long been seen as a good place for people to retire to and the population is ageing, resulting in falling rolls at the schools. The cost of delivering education in rural areas is proportionately higher than in urban areas, yet current public funding formulas fail to take account of sparsity and rurality. As a result, Bishop's Castle's two schools suffer from problems of financial viability. They have insufficient resources to recruit and retain specialist staff, especially in the area of special educational needs. The town is no longer able to provide post- 16 education, forcing students to travel up to 40 miles each way on a daily basis. This dependence on transport prevents many students from taking part in after-school and extra-curricular activities.

Between 2010 and 2017, £103 million was cut from bus support across England and Wales. This represents a 32 percent reduction in budget overall. Some rural authorities have seen very significant reductions, with Shropshire cutting more than 60 percent of its funding. Shropshire Council are currently proposing to cut this even further. For Bishop's Castle, this would result in just one or two buses per day to Shrewsbury, the nearest large town, instead of five. This threatens student courses, jobs and the health and social care of the community and is the subject of vigorous local protest. 


\section{DISCUSSION}

Bishop's Castle has a long history of responding creatively to external challenges. It demonstrates strong resilience, as shown by the following three examples illustrating issues of employment, housing and community services.

Employment and affordability of housing are the two main challenges for Bishop's Castle. In response, a Community Land Trust was established to provide affordable housing. It builds new homes or renovates existing properties to rent to local people. It also provides premises for business that deliver jobs for the benefit of the community. The rust is working to secure a business park through a Community Asset Transfer from Shropshire Council aimed at stimulating local employment opportunities, particularly for small and start-up businesses.

Maintaining the future of Bishop's Castle's SpArC Leisure Centre is a particular challenge, with local government funding cuts combined with a small population making it hard to achieve economies of scale. A well-organised "Save the SpArC" campaign began in 2016 in response to fears that the leisure centre might close after Shropshire Council announced it would withdraw funding. It persuaded the council to change their mind and designate SpArC as one of only two "rural hubs" in the whole county to escape the axe.

When Bishop's Castle's public library was threatened with closure in 2016, the town's own Enterprise Company took control from Shropshire Council through a Community Asset Transfer. It now runs the library, directly employing its staff. Enterprise SW Shropshire has been "trading for social benefit" since 1996, focusing on providing services that help the rural economy such as a dropin IT centre, business support, equipment loan service and the local theatre.

In 2005 the EU developed a set of eight main characteristics by which the sustainability of a settlement could be assessed (Figure 8). Known as the Bristol Accord, this agreement has become a standardised way of comparing communities across Europe.

01 - ACTIVE, INCLUSIVE AND SAFE
02 - WELL RUN
03 - WELL CONNECTED
04 - WELL SERVED
05 - ENVIRONMENTALLY SENSITIVE
06 - THRIVING
07 - WELL DESIGNED AND BUILT
08 - FAIR FOR EVERYONE

Figure 8. The eight characteristics of a sustainable community. Source: Author-adapted version of Office of the Deputy Prime Minister (2005, pp. I 2-14).

\begin{tabular}{|l|l|c|}
\hline \multicolumn{1}{|c|}{ Positive Characteristics } & $\%$ \\
\hline 02 & People in Bishops's Castle feel proud of their Town & $94 \%$ \\
\hline 01 & Bishop's Castle people look out for one another and this helps to create a strong community & $92 \%$ \\
\hline 01 & People feel safe within our community & $92 \%$ \\
\hline 01 & There are shared activities in Bishop's Castle which help to create a strong sense of community & $91 \%$ \\
\hline 05 & Bishop's Castle is relatively free of litter and graffiti & $91 \%$ \\
\hline 06 & Local businesses contribute to / support the local community & $84 \%$ \\
\hline 05 & $\begin{array}{l}\text { This is a community that is concerned about the effects of pollution, is careful about waste } \\
\text { disposal and encourages recycling }\end{array}$ & $82 \%$ \\
\hline 05 & This is a community that respects the environment and uses resources carefully & $77 \%$ \\
\hline 07 & Bishop's Castle Town is in a good condition and is well looked after & $76 \%$ \\
\hline 03 & We have good facilities to encourage safe local walking and cycling & $70 \%$ \\
\hline 05 & $\begin{array}{l}\text { This is a community that tries to minimise the effects of climate change through energy efficiency } \\
\text { and the use of renewables }\end{array}$ & $67 \%$ \\
\hline 01 & Most people in Bishop's Castle feel part of the community and there are no excluded groups & $65 \%$ \\
\hline 08 & Our community respects the rights and aspirations of all local people & $60 \%$ \\
\hline
\end{tabular}

Table I. Survey results - positive characteristics of Bishop's Castle. Source: Author. 


\begin{tabular}{|c|l|c|}
\hline \multicolumn{2}{|c|}{ Negative Characteristics } & $\%$ \\
\hline 07 & The price of local housing does not create problems for local people & $5 \%$ \\
\hline 07 & The price of housing does not prevent people who work locally from living locally & $10 \%$ \\
\hline 03 & $\begin{array}{l}\text { Local people are able to travel to work, to shop and to access education and other services } \\
\text { using public transport and are not entirely reliant on the private car }\end{array}$ & $11 \%$ \\
\hline 07 & There is enough housing available to meet the needs of local people & $12 \%$ \\
\hline 06 & $\begin{array}{l}\text { There is a range of jobs available for local people and they are not reliant upon one or two big } \\
\text { employers }\end{array}$ & $18 \%$ \\
\hline 06 & $\begin{array}{l}\text { The local economy provides employment opportunities for people in the community who wish } \\
\text { to work here }\end{array}$ & $25 \%$ \\
\hline 02 & $\begin{array}{l}\text { People feel well connected to services provided by Shropshire Council and other service } \\
\text { providers }\end{array}$ & $26 \%$ \\
\hline 03 & Our community is well connected with other settlements and the 'outside world' & $35 \%$ \\
\hline 03 & $\begin{array}{l}\text { The services that are available for our community are well used and are not under threat } \\
\text { through lack of use }\end{array}$ & $39 \%$ \\
\hline
\end{tabular}

Table 2. Survey results - negative characteristics of Bishop's Castle. Source: Author.

A recent survey of the Bishop's Castle community based on the characteristics noted in the Accord attracted more than 100 responses. The pride in and strength of the community is strikingly high. It is also a town very aware of environmental and 'green' issues (Table I).

Conversely, issues of housing, jobs and transport are also of concern to the community, as is common in rural settlements in the UK. It is in these areas that the sustainability of the community is under most threat. Having identified the issues most likely to destabilise the long-term cohesion of a community, what steps might be taken to mitigate their effects? A sustainable community is one which is empowered and proactive in meeting new challenges head-on.

An empowered community is one that is confident, resilient, energetic and independent. It is well networked and has a high degree of social capital. "It is confident enough to imagine a better future for itself, and is in a position to take control of that future. It has the breadth of vision to be able to enlist others and other agencies in helping it to deliver its ambitions." (Elliott, Chair of Land Reform Review Group, 20I4).

\section{A model for building a sustainable community}

The research and empirical evidence collated by the author, in the form of community surveys and interviews, has led to the development of the model outlined below as a strategy for achieving the long-term sustainability of a rural settlement like Bishop's Castle. By focussing on the following five aspects of community development, the intention is to strengthen the town's resilience and sustainability.

\section{Creating a sense of place}

Communities that are said to have a 'sense of place' are those with strong identity and civic pride that is deeply felt by inhabitants and visitors alike. As the aforementioned survey shows, Bishop's Castle has a very strong sense of community and pride. Events such as the annual Michaelmas Fair are critical in symbolising the community's cultural identity and manifesting what the community is about. The fair is about showcasing who and what the community is and fosters a huge sense of pride. It promotes a sense of belonging, or 'being part of the tribe.' It creates a shared understanding that 'this is a community that stands together', strong and against the world if necessary. 


\section{Community capacity-building and empowerment}

To paraphrase Haile Sellasie, the ultimate resource of a community is its people. Perhaps the most important factor in achieving a resilient and sustainable community is to enable local people to develop, implement and sustain their own solutions to problems in a way that helps them shape and exercise control over their physical, social, economic and cultural environments. If a strong sense of place exists, then building the capacity of the community and investing in social capital will result in a united and proactive response.

The Bishop's Castle Community Partnership was established to address a range of issues identified by the community. Its slogan asks the question: "Are you worried about: too few jobs; shortage of affordable housing ...?" and puts the challenge: "Want to do something about it?"'The aim is to empower the community to come together to recognise potential threats in the belief that community action is the best way to lead to change and improve outcomes for individuals. The partnership has instigated a number of projects where local people take responsibility for their own community - for example, Fight the Plastics, a campaign to tackle the problem of wasteful and unsustainable singleuse plastics; and Food Waste, where surplus local supermarket food is redistributed to Meals on Wheels and the local college canteen.

\section{Widening the horizons of the local community and challenging low aspirations, particularly relating to young people}

As the Resilience Compass shows, a sustainable community is one that is outward-looking, with a willingness to learn from other communities. Fostering links and networking spreads existing good practice and challenges esoteric and narrow ideologies by raising expectations.

The Bishop's Castle About Music Project has run for ten years with the aim of developing and supporting youth music groups. It has engaged many young people, providing them with a reason to stay in the town or to return there to live, following university studies.

The global issue of climate change and the resultant Extinction Rebellion has motivated younger people to start taking a greater responsibility for their own futures. In Bishop's Castle, young activists are designing a community café and drop-in centre. The Thrive Lounge (personal communication, H. Robson, May 2019) will be a space that promotes the mental health and well-being of the community. It is a place to help build an optimistic, vibrant community, full of opportunity and prosperity.

\section{Promoting digital transformation}

Fast broadband connectivity empowers rural communities by enabling locational independence - the ability to work anywhere. The European Commission defines Smart Villages as rural areas where traditional and new networks and services are enhanced by means of digital telecommunication technologies, innovation and the better use of knowledge. They use digital technologies to improve economic activity and the quality of life, accessing knowledge and markets previously only available to urban areas (European Commission, 20 I8a).

\section{Finding local solutions to public funding cuts and the centralisation of public services}

The 2015 Scottish Community Empowerment Act and the House of Lords Rural Strategy Select Committee both advocate a 'place-based' approach for future rural policies and services. An empowered rural community has the best understanding of what services it needs. Too often, service provision designed for urban areas is not appropriate or affordable for rural communities. Rural services may be improved and made more sustainable through the deployment of technology and through community-led actions and projects. 


\section{CONCLUSION}

Recent years of political and economic austerity now threaten the existence of many rural settlements in the UK. A lack of local jobs and affordable housing is resulting in a circle of decline. Too often service provision designed for urban areas is not appropriate or affordable for rural communities.

Bishop's Castle has a track-record of self-determination and identifying creative solutions to problems. For example, the Community Asset Transfer of the town's public library through establishing a company "trading for social benefit" is not dependent on a volunteer workforce and, as a result, has become a sustainable service for the community.

Both 'resilience' and 'sustainability' function together as an integrated system when one is considering the long-term prosperity of rural communities. Bishop's Castle is a community working towards resilience and sustainability and developing a model for how this might best be achieved.

\section{ACKNOWLEDGMENTS}

Dr Jean Ross, Associate Professor, Otago Polytechnic, New Zealand

Daphne DuCros, Hope Robson and Mike Watkins, Bishop's Castle Community Partnership

Mike Ashwell, Director, Enterprise SW Shropshire

Jean Shirley, Chair, SpArC Campaign, Bishop's Castle

Jim Gaffney, Chair, Bishop's Castle Community Land Trust

Keith Whiddon (BEd (Hons) London) (미 0000-000 I-7337-0449) originally a teacher of geography spent several years leading on the strategic development of ICT in education as a school adviser and inspector. After moving to Bishop's Castle in 2014, Keith now lives as a musician and community activist. He is a school governor and chairs both the Bishop's Castle Community Partnership and the Michaelmas Fair.

Correspondence to: Keith Whiddon. Email: keith.whiddon@btinternet.com 


\section{REFERENCES}

Alvarez, M. (20I5). What do we mean by Sustainable Communties? Retrieved from https://nestainvestments.org.uk/wp-content/ uploads/2015/0I/What-do-we-mean-by-Sustainable-Communties.pdf

Barrow, M. (2018). Future Shropshire. Retrieved from https://rsnonline.org.uk/images/meetings/regional-seminars/I9-20-programme/ west-midlands-2019/Mark_Barrow_Presentation.pdf

UK Office for National Statistics. (2011). 2011 Census in England and Wales. Retrieved from https://www.ons.gov.uk/ census/20I I census

Elliot, A. (2014). The Scottish government's Land Reform Review Group. Retrieved from https://www2.gov.scot/Topics/archive/reviews/ land-reform

European Commission. (20I8a). Smart Villages: Revitalising rural services through social and digital innovation. Retrieved from https://enrd.ec.europa.eu/sites/enrd/files/tg_smart-villages_leaflet.pdf

European Commission. (2018b). Smart Villages: Revitalising rural services (EU Rural Review 26). Retrieved from https://enrd. ec.europa.eu/publications/eu-rural-review-26-smart-villages-revitalising-rural-services_en

House of Commons Library. (2019). NHS key statistics: England, May 2019. Retrieved from ttps://researchbriefings.parliament.uk/ ResearchBriefing/Summary/CBP-728I

House of Lords Select Committee on the Rural Economy. (2019). Time for a strategy for the rural economy. Retrieved from https:// publications.parliament.uk/pa/ld20 I7/9/ldselect/ldrurecon/330/330.pdf

Maslow, A. H. (1943). A theory of human motivation. Retrieved from http://psychclassics.yorku.ca/Maslow/motivation.htm

Musker, R. (20।5). Applying ontologies to resilience and sustainability concepts in food systems. Retrieved from

https://ethz.ch/content/dam/ethz/special-interest/usys/ias/enhancing-resilience-dam/documents/Musker_UCLPresentation_20 I 5. pdf

NHS Future Fit. (2019). Shaping healthcare together. Retrieved from

https://www.nhsfuturefit.org/

Office of the Deputy Prime Minister. (2005). Bristol Accord: Conclusions of ministerial informal on sustainable communities in Europe. Retrieved from https://www.eib.org/attachments/jessica_bristol_accord_sustainable_communities.pdf_

Shropshire Council. (2017-18). Bishop's Castle market town profile. Retrieved from https://shropshire.gov.uk/media/968I/bishopscastle.pdf

The Community Empowerment (Scotland) Act. (2015). Retrieved from http://www.legislation.gov.uk/asp/20I5/6/contents/enacted

Wilding, N. (20II). Exploring community resilience. Retrieved from: https://www.carnegieuktrust.org.uk/publications/exploringcommunity-resilience/ 